Journal of Animal \& Plant Sciences, 32(1): 2022, Page: 60-68

ISSN (print): 1018-7081; ISSN (online): 2309-8694

https://doi.org/10.36899/JAPS.2022.1.0402

\title{
MESOWEAR AND PALEODIETS OF MIDDLE MIOCENE MAMMALS FROM CHABBAR SYEDAN, PUNJAB, PAKISTAN
}

\author{
M. K. Nawaz ${ }^{1}$, K. Aftab ${ }^{2}$, M. A. Khan 1 , S. G. Abbas ${ }^{1}$ M. Asim¹, M. A. Babar ${ }^{3}$, M. Hussain ${ }^{2}$ and M. Akhtar ${ }^{4}$ \\ ${ }^{1}$ Dr. Abu Bakr Fossil Display and Research Centre, Department of Zoology, University of the Punjab, Quaid-e-Azam \\ Campus, Lahore; ${ }^{2}$ Department of Zoology, University of Gujrat, Gujrat; ${ }^{3}$ Department of Zoology, University of Okara, \\ Okara; ${ }^{4}$ Department of Zoology, University of Central Punjab, Lahore \\ *Corresponding author's email: dr.kiran@uog.edu.pk
}

\begin{abstract}
The paleodiets of seven mammalian species from Chabbar Syedan are analysed using dental mesowear. Mesowear results suggest that Miotragocerus gluten, Eotragus sp., Giraffokeryx punjabiensis, Giraffa priscilla, Dorcatherium minus had attrition dominant diet and fall within dietary spectra of browsers to occasional mixed feeders. Gazella sp. and Listriodon pentapotamiae had an intermediate attrition-abrasion wear signatures and were mixed feeders or browse dominated mixed feeders. The mesowear data of Chabbar Syedan mammals were compared with previous palaeodietary studies and it showed that the results are most closely in line with the previous studies. These results also indicate that during Middle Miocene of Chabbar Syedan, browsing mammals were dominant and ecological conditions were more favorable for browsers than to exclusive grazers.
\end{abstract}

Keywords: Mesowear, Miocene, Chinji, Mammals, Paleodiets, Siwaliks

Published first online October 14, 2021

Published final January 07, 2022.

\section{INTRODUCTION}

Dental mesowear is a valuable technique in decoding paleodiets of ungulates and it is based on studying an animal's tooth wearing fingerprint for the determination of paleodiets of different extinct and extant species (Fortelius and Solounias, 2000; Solounias et al., 2010, 2012). This method is considered as a significant and easy method of paleodietary inferences (Rivals and Semprebon, 2006; Semprebon and Rivals, 2007; Mihlbachler et al., 2011; Frazer and Theodor, 2013). Since the introduction of mesowear investigation, it has been applied to upper second molars (Fortelius and Solounias, 2000), later (Kaiser and Solounias, 2003) extended this method to four tooth positions (P4-M3) which has been exercised recurrently in other mesowear analyses (Semprebon et al., 2004; Rivals and Semprebon, 2006; Rivals et al., 2007). The tooth model was further extended to cover lower molars of equids, rhinoceroses, ruminants, marsupial teeth, rodent and lagomorph teeth (Hernesniemi et al., 2011; Butler et al., 2014; Frazer et al., 2014; Ulbricht et al., 2015). It is used to counter some wide-ranging issues regarding paleoenvironment and characterize the average diet of ungulates by approximately enumerating the comparative attritionabrasion amounts encountered by the premolars and molars (Fortelius and Solounias, 2000). By evaluating the data acquired from the existing animals with recognized diets, the paleodietary inclinations of extinct taxa can be established (Fortelius and Solounias, 2000).
Chabbar Syedan site is located at the base of Bakrala ridge, district Jhelum, Punjab, Pakistan (Fig. 1). It belongs to the middle and upper part of the Chinji Formation (Aftab et al., 2015; Abbas et al., 2016). The Chinji fauna is in favor of Middle Miocene age owing to comparison of the material with many representatives of the fauna point toward Middle Miocene age (Pilgrim, 1937, 1939; Nawaz et al., 2019). Most of the fossils are mainly present in the grit type sandstone and in the pseudo conglomerate, conglomerate, and clay (Nawaz et al., 2019).

In Pakistan, Tariq (2010) provide the only major contribution in the paleodietary studies which include both microwear and mesowear analysis of extant, and extinct ungulates from Pakistani Siwaliks. The other contribution made by Tariq and Jahan (2014) through investigation of dietary evaluations and paleoecology of Giraffokeryx punjabiensis with the help of mesowear-I, mesowear-II and hypsodonty methods. Belmaker et al. (2007) studied the Siwalik Hipparionini, Tragoceridus sp. and large bovid Selenoportax. No other valuable work has been done so far to decode paleodiet by using dental mesowear on the mammalian fossils of Pakistani Siwaliks. The current mesowear analysis of Chabbar Syedan mammals is used to determine paleodiet and try to answer some difficult questions about paleoenvironment of the area. This pioneering mesowear analysis of Chabbar Syedan mammals will attract paleoecologists and add new information in the field of paleoecology. 
Abbreviations: $\quad$ PUPC, Punjab University Paleontological Collection; Ma, million years ago; $\mathrm{P}$, upper premolar; M, upper molar; $\mathrm{p}$, lower premolar; $\mathrm{m}$, lower molar; OR, occlusal relief; CS, cusp shape; I, low; h, high; s, sharp; r, round; b, blunt.

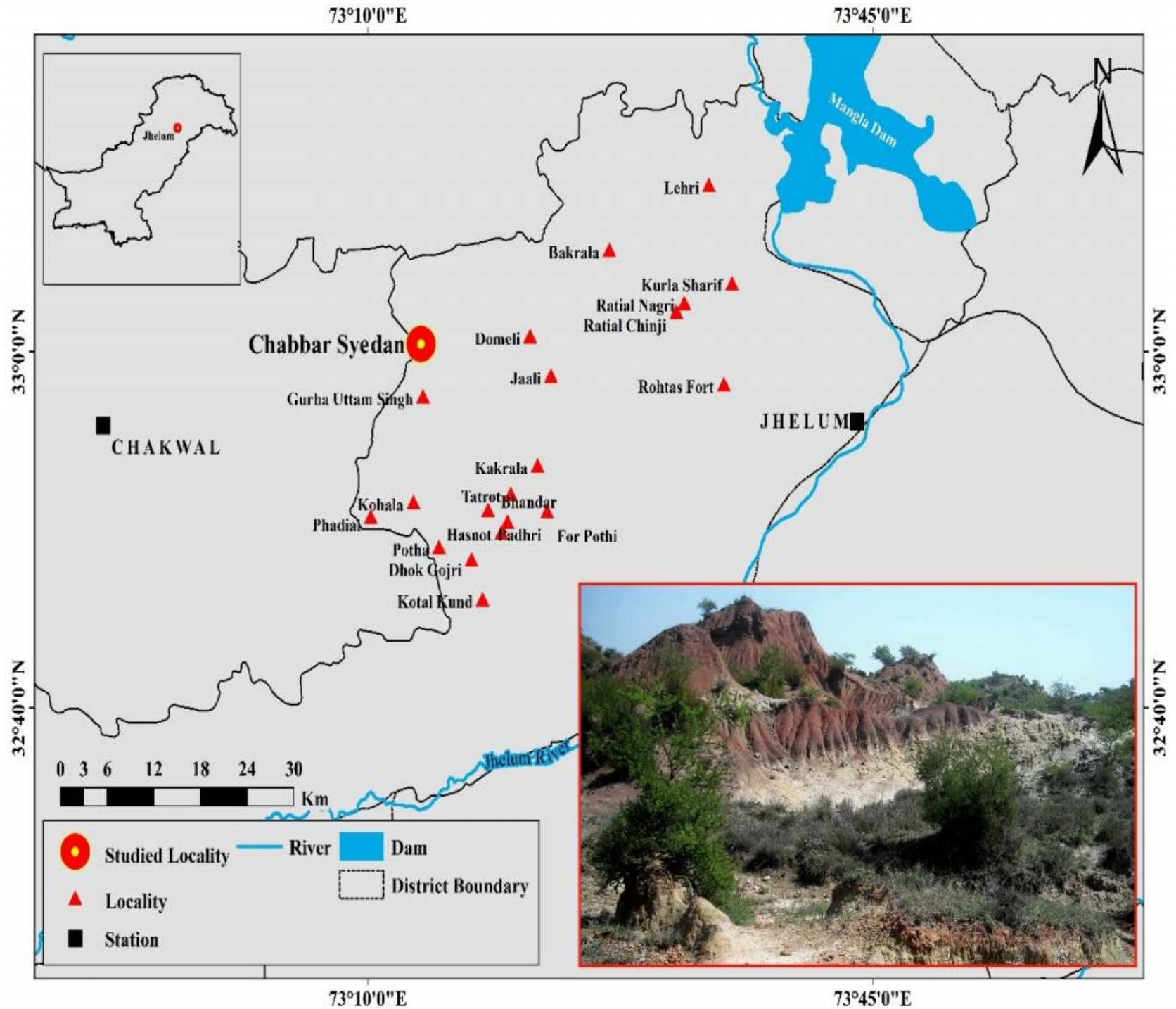

Fig. 1. Location of the Chabbar Syedan site in Jhelum district with outcrops exposed in the vicinity of the village.

\section{MATERIALS AND METHODS}

The studied material was collected from Chabbar Syedan (33 00' 16.1" N; 73 13' 29.0" E) site during the fieldwork carried out by Muhammad Khalil Nawaz for the compilation of his $\mathrm{PhD}$ dissertation. Fifty maxillary and mandibular teeth were selected for the analysis of dental mesowear. To enhance the sample size, both upper and lower dentition (P4-M3 and m1-m3) was included. All studied specimens are housed at "Dr. Abu Bakr Fossil Display and Research Centre, Department of Zoology, University of the Punjab, Lahore" and study methods follow of Fortelius and Solounias (2000). Specimens with well-preserved buccal cusps were favored. Teeth without obvious wear facet (younger individuals) as well as overly worn teeth (older individuals) were excluded from mesowear analyses (Fortelius and Solounias, 2000; Rivals et al., 2007).

Dental mesowear has been performed by focusing enamel band 1 to spotlight the surfaces of enamel wherever the buccal wall meets the occlusal surface. By means of a hand lens, teeth were examined at close range and the buccal cusps of maxillary and mandibular teeth were scored in terms of occlusal relief (OR) and cusp shape (CS) as given in Table 1. Depending on how high the cusp rises above the valley between them, the occlusal relief (OR) is classified as high (h) or low (l) as shown in (Fig. 2). Cusp shape is the 
second mesowear variable which consists of three features: sharp (s), round (r) and blunt in accordance with the level of facet growth (Fig. 2). A sharp cusp ends to a tip along with no rounded area between the mesial and distal facets. A rounded cusp has a noticeably rounded tip whereas a blunt cusp be short of distinctive facets altogether.

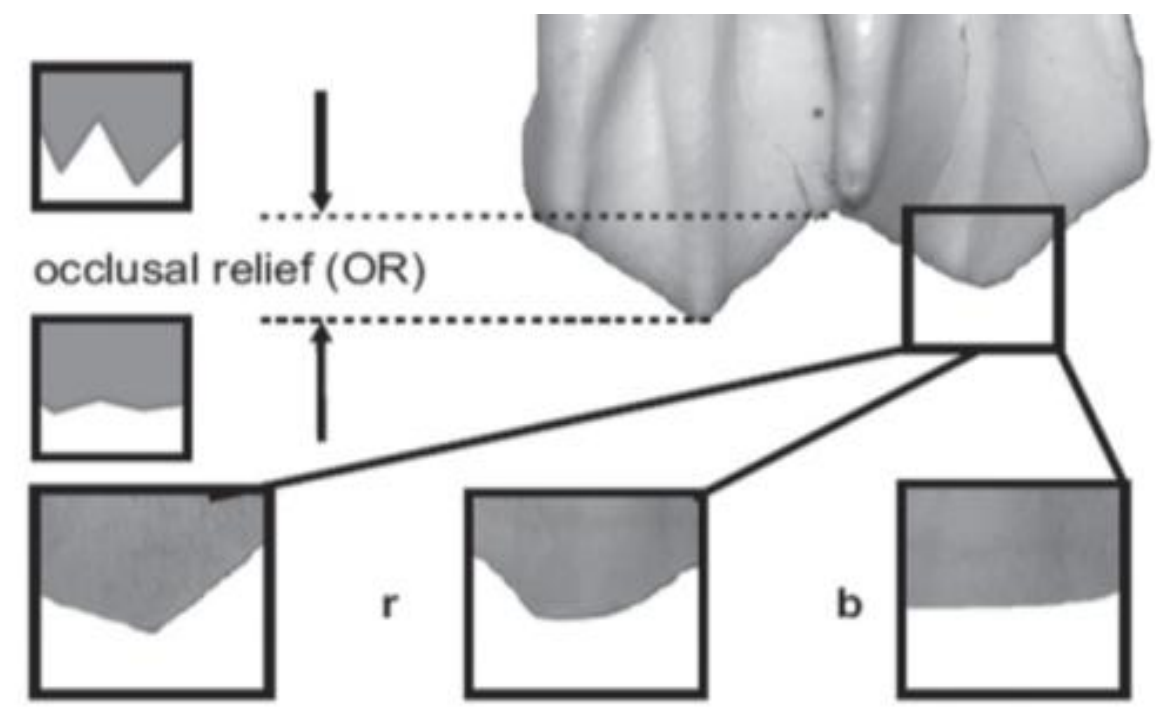

\section{cusp shape (CS)}

Fig. 2. The mesowear scoring convention for cheek teeth as defined by Fortelius and Solounias (2000) for upper second molars. The convention is extended to other tooth positions (P4-M3, m1-m3). The occlusal relief (OR) may be scored "high" (h) or "low" (l), the cusp shape (CS) is classified as "sharp" (s), "round" (r), and "blunt" (b).

Table 1. Mesowear scores of five mammalian species of Lower Siwaliks. OR $=$ Occlusal Relief, $C S=$ Cusp Shape. Variables are: $\mathbf{I}=$ low, $\mathbf{h}=$ high, $\mathbf{s}=\operatorname{sharp}, \mathbf{r}=$ round, $\mathbf{b}=$ blunt. As defined by Fortelius and Solounias (2000).

\begin{tabular}{|c|c|c|c|c|c|}
\hline Sr\# & Taxon & Number & Position & OR $(\mathrm{h} / \mathrm{l})$ & $\operatorname{CS}(\mathrm{s} / \mathrm{r} / \mathrm{b})$ \\
\hline 1 & Miotragocerus gluten & PUPC 16/228 & rP4 & 1 & $\mathrm{r}$ \\
\hline 2 & & PUPC 16/171 & 1M1 & $\mathrm{h}$ & $\mathrm{s}$ \\
\hline 3 & & PUPC 16/174 & rM2 & 1 & $\mathrm{r}$ \\
\hline 4 & & PUPC 16/175 & rM2 & $\mathrm{h}$ & $\mathrm{s}$ \\
\hline 5 & & PUPC 16/176 & $1 \mathrm{M} 2$ & 1 & $\mathrm{r}$ \\
\hline 6 & & PUPC 16/313 & $\mathrm{rM} 2$ & $\mathrm{~h}$ & $\mathrm{r}$ \\
\hline 7 & & PUPC 19/73 & rM2 & $\mathrm{h}$ & $\mathrm{s}$ \\
\hline 8 & & PUPC 17/195 & rM3 & $\mathrm{h}$ & $\mathrm{s}$ \\
\hline 1 & Eotragus sp. & PUPC 17/198 & $\operatorname{lm} 1$ & $\mathrm{~h}$ & $\mathrm{~s}$ \\
\hline 2 & & PUPC 16/323 & $\operatorname{lm} 2$ & $\mathrm{~h}$ & $\mathrm{~s}$ \\
\hline 3 & & PUPC 18/17 & $\mathrm{rm} 3$ & $\mathrm{~h}$ & $\mathrm{~s}$ \\
\hline 4 & & PUPC 16/326 & $\operatorname{lm}$ & 1 & $\mathrm{r}$ \\
\hline 1 & Gazella sp. & PUPC 16/315 & $\mathrm{rP} 4$ & 1 & $\mathrm{r}$ \\
\hline 2 & & PUPC 19/83 & 1P4 & 1 & $\mathrm{r}$ \\
\hline 3 & & PUPC 16/316 & 1P4 & 1 & $\mathrm{r}$ \\
\hline 4 & & PUPC $17 / 199$ & $\mathrm{rM} 2$ & $\mathrm{~h}$ & $\mathrm{r}$ \\
\hline 5 & & PUPC 16/320 & $1 \mathrm{M} 2$ & $\mathrm{~h}$ & $\mathrm{~s}$ \\
\hline 6 & & PUPC 16/321 & rM2 & $\mathrm{h}$ & $\mathrm{s}$ \\
\hline 7 & & PUPC 19/72 & rM2 & 1 & $\mathrm{r}$ \\
\hline 8 & & PUPC 17/197 & rM3 & 1 & $\mathrm{r}$ \\
\hline 9 & & PUPC 19/76 & rM3 & 1 & $\mathrm{r}$ \\
\hline
\end{tabular}




\begin{tabular}{|c|c|c|c|c|c|}
\hline 10 & & PUPC 16/177 & $\operatorname{lm} 2$ & $\mathrm{~h}$ & $\mathrm{~s}$ \\
\hline 11 & & PUPC $16 / 322$ & $\mathrm{rm} 3$ & $\mathrm{~h}$ & $\mathrm{r}$ \\
\hline 12 & & PUPC 16/227 & $\operatorname{lm} 3$ & 1 & $\mathrm{~b}$ \\
\hline 13 & & PUPC 16/226 & $\mathrm{rm} 3$ & $\mathrm{~h}$ & $\mathrm{~s}$ \\
\hline 1 & Giraffokeryx punjabiensis & PUPC 19/79 & 1P4 & 1 & $\mathrm{r}$ \\
\hline 2 & & PUPC 19/80 & rP4 & $\mathrm{h}$ & $\mathrm{s}$ \\
\hline 3 & & PUPC 16/219 & P4 & $\mathrm{h}$ & $\mathrm{s}$ \\
\hline 4 & & PUPC 16/217 & rM2 & $\mathrm{h}$ & $\mathrm{s}$ \\
\hline 1 & Giraffa Priscilla & PUPC 16/167 & $\operatorname{lp} 4-\operatorname{lm} 2$ & 1 & $\mathrm{r}$ \\
\hline 2 & & PUPC 16/212 & $\mathrm{rm} 1$ & $\mathrm{~h}$ & $\mathrm{~s}$ \\
\hline 3 & & PUPC 16/222 & $\operatorname{lm}$ & 1 & $\mathrm{r}$ \\
\hline 4 & & PUPC 19/70 & $\mathrm{rm} 2$ & $\mathrm{~h}$ & $\mathrm{~s}$ \\
\hline 5 & & PUPC 16/214 & $\mathrm{rm} 3$ & $\mathrm{~h}$ & $\mathrm{~s}$ \\
\hline 6 & & PUPC 19/67 & $\mathrm{rm} 3$ & $\mathrm{~h}$ & $\mathrm{~s}$ \\
\hline 1 & Dorcatherium minus & PUPC 16/223 & rM1 & 1 & $\mathrm{r}$ \\
\hline 2 & & PUPC 17/194 & rM1 & $\mathrm{h}$ & $\mathrm{s}$ \\
\hline 3 & & PUPC $17 / 193$ & $1 \mathrm{M} 2$ & $\mathrm{~h}$ & $\mathrm{~s}$ \\
\hline 4 & & PUPC 16/201 & rM2 & $\mathrm{h}$ & $\mathrm{r}$ \\
\hline 5 & & PUPC $16 / 308$ & $1 \mathrm{M} 3$ & $\mathrm{~h}$ & $\mathrm{~s}$ \\
\hline 6 & & PUPC 16/312 & $\mathrm{rm} 2$ & 1 & $\mathrm{r}$ \\
\hline 7 & & PUPC 19/75 & $\mathrm{rm} 2$ & $\mathrm{~h}$ & $\mathrm{~s}$ \\
\hline 8 & & PUPC 16/194 & $\operatorname{lm} 3$ & $\mathrm{~h}$ & $\mathrm{~s}$ \\
\hline 9 & & PUPC $16 / 309$ & $\mathrm{rm} 3$ & $\mathrm{~h}$ & $\mathrm{~s}$ \\
\hline 1 & Listriodon pentapotamiae & PUPC 16/305 & rP4 & 1 & $\mathrm{r}$ \\
\hline 2 & & PUPC 18/56 & IP4 & 1 & $\mathrm{r}$ \\
\hline 3 & & PUPC 18/57 & IP4 & $\mathrm{h}$ & $\mathrm{s}$ \\
\hline 4 & & PUPC 16/304 & $1 \mathrm{M} 2$ & $\mathrm{~h}$ & $\mathrm{~s}$ \\
\hline 5 & & PUPC 16/303 & rM2 & $\mathrm{h}$ & $\mathrm{r}$ \\
\hline 6 & & PUPC 16/204 & $1 \mathrm{M} 3$ & 1 & $\mathrm{~b}$ \\
\hline
\end{tabular}

Occlusal relief as well as cusp sharpness are reliant variables. Elevated occlusal relief cusps tend to be sharper as judge against low relief cusps, in addition to cusps with zero relief are evidently blunt. Every specimen has been documented for occlusal relief and cusp shape arranged in tabulated form. Individual percentages of each species cusps displaying high, low relief and shapes such as sharp, round, and blunt were calculated. The percentages of each category $(\%$ high, $\%$ low, $\%$ sharp, $\%$ round, $\%$ blunt) were used to group taxa into dietary categories. By using the tabulated data of mesowear variables, histograms were plotted (Fig. 3, 4).

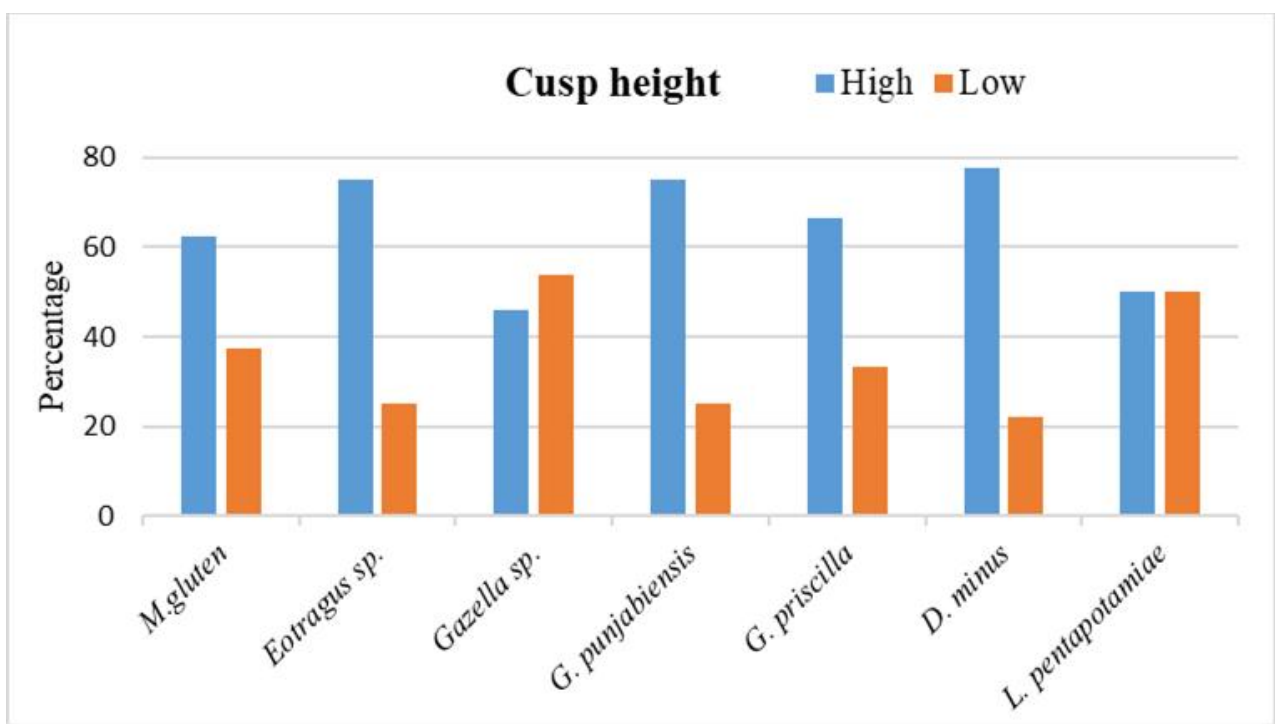

Fig. 3. Histogram of mesowear variables \% high cusps and \% low cusps for the Chabbar Syedan mammals. 


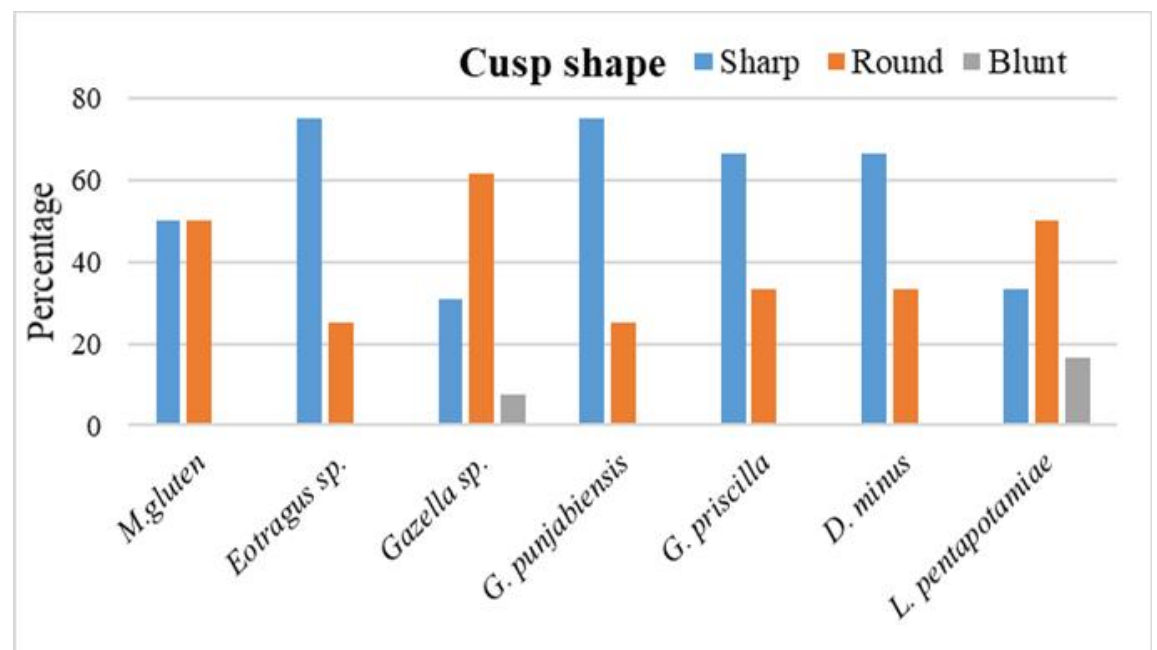

Fig. 4. Histogram of mesowear variables \% sharp cusps, \% round cusps and \% blunt cusps for the Chabbar Syedan mammals.

\section{RESULTS}

The mesowear results of following seven mammalian species; Miotragocerus gluten, Eotragus sp., Gazella sp., Giraffokeryx punjabiensis, Giraffa priscilla, Dorcatherium minus and Listriodon pentapotamiae are summarized in (Fig. 3, 4; Table 2). These data show few differences in the wear types on the teeth of abovementioned mammalian species, splitting them into two groups; Miotragocerus gluten, Eotragus sp., Giraffokeryx punjabiensis, Giraffa priscilla and Dorcatherium minus have high percentages of sharp and high cusps while Gazella sp. and Listriodon pentapotamiae have intermediate results of mesowear variables. on the basis of results, it is speculated that the first group had highly attritional diet and hence, fall in browsers to mixed feeders categories in dietary spectra and second group fall in mixed feeders or browse dominated mixed feeders categories in dietary spectra. The percentages of mesowear variables showed that overall, 62\% specimens scored high relief and 38\% low relief, sharp cusp 52\%, round $44 \%$ and $4 \%$ blunt (Table 2). These mesowear results depict that, conditions were more advantageous for browsers than to exclusive grazers during the Middle Miocene in the study area. These paleodietary assessments of seven studied species of Chabbar Syedan mammals showed no signs of exclusive grazing.

Statistical analyses were performed by using independent t-test and one-way ANOVA to test the significant differences in mesowear variables (occlusal relief and cusp shape) with significance set at $\mathrm{p}<0.05$. Independent samples t-test revealed no significant differences between the high and low relief mesowear variables (Fig. 5; Table 3). One-way Anova test was applied on the cusp shape and found that, means of CS differ significantly at $\mathrm{P}=0.002 \leq 0.05$ (Fig. 6; Table 4).

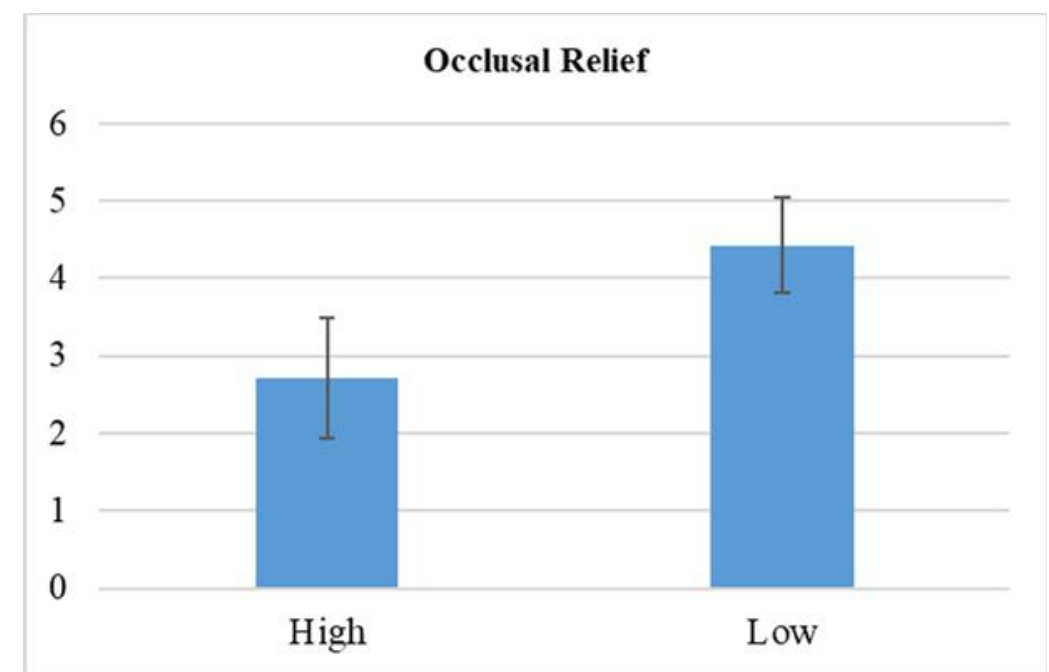

Fig. 5. Difference between means of Occlusal relief (OR) analyzed by independent t-test. 


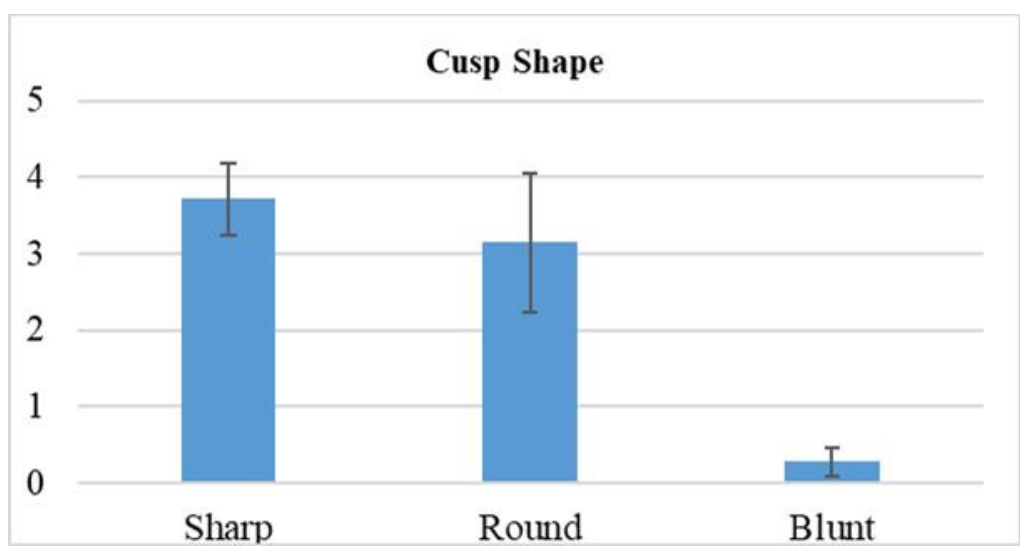

Fig. 6. Difference between means of Cusp shape (CS) analyzed by one-way Anova.

Table 2. Mean mesowear variable values of seven mammalian species of Chabbar Syedan with percentages of OR (High and Low) and CS (Sharp, Round and Blunt).

\begin{tabular}{|c|c|c|c|c|c|c|c|c|c|c|c|}
\hline \multirow{2}{*}{ Taxon } & \multirow{2}{*}{$\mathbf{N}$} & \multicolumn{2}{|c|}{ OR } & \multicolumn{3}{|c|}{ CS } & \multicolumn{2}{|c|}{ OR } & \multicolumn{3}{|c|}{ CS } \\
\hline & & $\mathrm{h}$ & 1 & $\mathrm{~s}$ & $\mathrm{r}$ & $\mathrm{b}$ & $\%$ High & \%Low & \%Sharp & \%Round & \%Blunt \\
\hline Miotragocerus gluten & 8 & 5 & 3 & 4 & 4 & 0 & 62.5 & 37.5 & 50 & 50 & 0 \\
\hline Eotragus sp. & 4 & 3 & 1 & 3 & 1 & 0 & 75 & 25 & 75 & 25 & 0 \\
\hline Gazella sp. & 13 & 6 & 7 & 4 & 8 & 1 & 46.15 & 53.84 & 30.76 & 61.53 & 7.69 \\
\hline Giraffokeryx punjabiensis & 4 & 3 & 1 & 3 & 1 & 0 & 75 & 25 & 75 & 25 & 0 \\
\hline Giraffa priscilla & 6 & 4 & 2 & 4 & 2 & 0 & 66.66 & 33.33 & 66.66 & 33.33 & 0 \\
\hline Dorcatherium minus & 9 & 7 & 2 & 6 & 3 & 0 & 77.77 & 22.22 & 66.66 & 33.33 & 0 \\
\hline Listriodon pentapotamie & 6 & 3 & 3 & 2 & 3 & 1 & 50 & 50 & 33.33 & 50 & 16.66 \\
\hline
\end{tabular}

Table 3. Difference between means of Occulusal relief (OR) analyzed by independent t-test.

\begin{tabular}{cllccc}
\hline Sr. no. & OR & Mean \pm SE & F value & P value & Df \\
\hline 1 & High & $2.7143 \pm .77810$ & .005 & .947 & 1 \\
2 & Low & $4.4286 \pm .61168$ & .04 & 1 \\
\hline
\end{tabular}

Table 4. Difference between means of Cusp shapes (CS) analyzed by one-way Anova.

\begin{tabular}{lllccc}
\hline Sr. No. & CS & Mean \pm SE & F value & P value & Df \\
\hline 1 & Sharp & $3.7143 \pm .47380$ & & & \\
2 & Round & $3.1429 \pm .91101$ & 9.300 & .002 & 2 \\
3 & Blunt & $.2857 \pm .18443$ & & & \\
\hline
\end{tabular}

\section{DISCUSSION}

During mastication, the dental enamel process largely shaped. In general, browsing individuals consume foliage from bushes and trees experience more attrition whereas grazing species that consume grasses experience more abrasion. According to current mesowear outcomes, mammalian fauna of Chabbar Syedan ranged from browsers to mixed feeders. Miotragocerus gluten, Eotragus sp., Giraffokeryx punjabiensis, Giraffa priscilla and Dorcatherium minus display high relief and sharp cusps which suggest that they were browsers. Gazella sp. and Listriodon pentapotamiae depict intermediate number of low and high relief cusps with rounded tips relying on their diet which is governed by browsing or occasional grazing, thus fall in mixed feeders dietary category. The worn occlusal surface relief as well as sharpness provide a strong signal of the plant material roughness consumed by the hoofed mammals and has been revealed the grass volume in diet specifically (Kaiser et al., 2013; Kubo and Yamada, 2014; Saarinen and Lister, 2016).

Dental mesowear signatures of Dorcatherium minus display considerable quantity of high as well as sharp cusps. Dorcatherium minus is a member of characteristic browsing guild representatives such as Miotragocerus, Eotragus, Tragoportax, Selenoportax, Elachistoceras and Dorcabune (Solounias et al., 1995; 
Barry et al., 2005; Khan and Akhtar, 2013). Miotragocerus gluten exhibit mesowear pattern of browsers in open habitats and mixed feeder in closed/semi-closed habitats whereas Eotragus sp. was a high-level browser (Tariq, 2010). Gazella sp. was a mixed feeder in closed habitats and showed significant deviation in their dietary habits that ranging from browsing to mixed feeding in addition to occasionally grass-dominated feeding (Tariq, 2010; Bernor et al., 2014). Mesowear analysis of Giraffokeryx punjabiensis by Tariq (2010) and Tariq and Jahan (2014) reflects its affinities to both browsing and mixed feeding extant analogues. Giraffa priscilla was a high-level browser and Listriodon pentapotamie was a medium sized regular browser in the study of the Tariq (2010). Gazella lydekkeri mesowear outcomes showed its affinities with two mixed feeding bovids: Ovibos moschatus and Aapyceros melampus (Tariq, 2010). Results (previous studies and present study) related to the dietary categories of seven studied species are given in (Table 3 ).

Table 5. Comparison of dietary categories of seven studied species with previous studies.

\begin{tabular}{|c|c|c|c|}
\hline $\begin{array}{l}\text { Sr. } \\
\text { No. }\end{array}$ & Species & Dietary category in previous studies & $\begin{array}{l}\text { Dietary category in } \\
\text { present Study }\end{array}$ \\
\hline 1. & Miotragocerus gluten & Browser or mixed feeder in closed habitats (Tariq, 2010) & Browser \\
\hline 2. & Eotragus sp. & High-level browser (Tariq, 2010) & Browser \\
\hline 3. & Gazella sp. & Mixed feeder in closed habitats (Badgley et al., 2008) & $\begin{array}{l}\text { Mixed feeder or browse } \\
\text { dominated mixed feeder }\end{array}$ \\
\hline 4. & $\begin{array}{l}\text { Giraffokeryx } \\
\text { punjabiensis }\end{array}$ & $\begin{array}{c}\text { Browser (Badgley et al., 2008) } \\
\text { Browser or mixed feeder in closed habitats (Tariq, 2010; } \\
\text { Tariq and Jahan, 2014) } \\
\text { Browser (as Giraffids) (Patnaik et al., 2019) }\end{array}$ & Browser \\
\hline 5. & Giraffa priscilla & $\begin{array}{c}\text { Browser (Badgley et al., 2008) } \\
\text { High-level browser (Tariq, 2010; Tariq and Jahan, 2014) } \\
\text { Browser (as Giraffids) (Patnaik et al., 2019) }\end{array}$ & Browser \\
\hline 6. & Dorcatherium minus & $\begin{array}{c}\text { Frugivore/browser (Badgley et al., 2008) } \\
\text { Selective browser (Tariq, 2010) } \\
\text { Browser (Dorcatherium sp.) (Patnaik et al., 2019) }\end{array}$ & Browser \\
\hline 7. & $\begin{array}{c}\text { Listriodon } \\
\text { pentapotamiae }\end{array}$ & $\begin{array}{l}\text { Browser (Badgley et al., 2008) } \\
\text { Regular browser (Tariq, 2010) }\end{array}$ & $\begin{array}{l}\text { Mixed feeder or browse } \\
\text { dominated mixed feeder }\end{array}$ \\
\hline
\end{tabular}

Tragulids mostly feed on fruits, leaves and infrequently on grass and their hypsodonty trend incline to support the evidence of browsing or occasional mixed feeding in Chinji formation (Khan and Akhtar, 2013; Batool et al., 2014). Ungulate diversity discloses dominance of browsers and browsing mixed feeders throughout Middle Miocene to earlier part of Late Miocene (Badgley et al., 2005, 2008). Based on the primate collection and other vertebrate taxa, Scott et al. (1999) have determined that the Chinji Formation climate was predominantly forested with heavy cover. Also, such type of vegetation was predominantly of $\mathrm{C}_{3}$ type. Hence, they suggested that the Chinji Formation localities likely represent uniformly forested conditions with a continuous canopy.

The restoration of paleoecology of ungulate fossils is mainly reliant on their paleodietary implications (Bibi and Gulec, 2008). Despite a very rich fossil record of extinct ruminants during Middle Miocene, rather insufficient direct estimates of diet by means of dental wear are available (Cantalapiedra et al., 2014). Studies on herbivores dietary assessments from Chinji Formation was based mostly on general comparisons with their living analogues (Barry et al., 2002; Samiullah et al., 2012). Middle Miocene (Chinji Formation) closed habitats shelter numerous species of browsers in conjunction with mixed feeders which point out the presence of tropical forests for the duration of 14-12 Ma as well as subtropical during $11 \mathrm{Ma}$. Giraffids from Middle Miocene shows similarities with extant browsers and mixed feeders, in addition they display no signs of grazing type of diet and thus cannot be grouped as exclusive browsers or grazers and the same trend is followed by giraffid species in present study.

Among ungulates, the diversity and species richness of the browsers and browsing mixed feeders was global phenomenon during Middle Miocene in Siwaliks of Pakistan (Badgley et al., 2005, 2008; Tariq, 2010), moreover, similar trend observed in the current mesowear analysis of Chabbar Syedan mammals. During Middle Miocene, the ungulates ecomorphic investigation indicates increase in forests with existence of mixed feeding bovids as well as hypsodont rhinoceroces nonetheless are still dominated by browsing ruminants 
and suids. Therefore, Middle Miocene climate of the Pakistani Siwaliks was predominantly forested with heavy cover of $\mathrm{C}_{3}$ type of vegetation.

Present work may assist as model for paleodietary studies in contemporaneous deposits and it will assist to address some tough questions of paleoecology of the area. It also signifies the fact that the climatic conditions of the Middle Miocene were more favorable for browsers than to grazers. Present study can be a road map for future research on paleodiets of Chabbar Syedan mammals, since mesowear can be used with other dietary proxy measures to make more accurate reconstructions of dietary behavior.

Conclusions: Mesowear analysis was conducted to evaluate the dietary categories of seven mammalian species from Chabbar Syedan based on different variables. Based upon the percentages of each category of mesowear variables, following can be concluded about seven studied species; Miotragocerus gluten, Eotragus sp., Giraffokeryx punjabiensis, Giraffa priscilla and Dorcatherium minus were browsers and perhaps occasional mixed feeders. Gazella sp. and Listriodon pentapotamiae fall in mixed feeder or browse dominated mixed feeders category in dietary spectra. Studied species display no signs of grazing type of diet and thus cannot be assigned as exclusive grazers. These paleodietary assessments indicate that, there was a browsing trend with a gradual shift towards mixed feeding during the Middle Miocene. These results also recommend existence of different habitats probably represent uniformly forested conditions with a continuous canopy during the Middle Miocene of Chabbar Syedan.

\section{REFERENCES}

Abbas, S.G., M.A. Khan, M.A. Babar, R. Shahid, M.K. Nawaz and M. Akhtar (2016). Some new fossils of Protanancus chinjiensis (Proboscidea, Mammalia) from Middle Miocene of Pakistan. Biol. 62(2): 345-349.

Aftab, K., Z. Ahmed, M.A. Khan and M. Akhtar (2015). Additional Giraffokeryx remains (Artiodactyla, Ruminantia, Giraffidae) from Chinji Formation of Lower Siwaliks, northern Pakistan. Pakistan J. Zool. 47: 1393-1403.

Badgley, C.E., S.V. Nelson, J.C. Barry, A.K. Behrensmeyer and T.E. Cerling (2005). Interpreting the past. In: essays on human primate and mammal evolution. Brill. Bost. 2946.

Badgley, C.E., J.C. Barry, M.E. Morgan, S.V. Nelson, A.K. Behrensmeyer, T.E. Cerling and D. Pilbeam (2008). Ecological changes in Miocene mammalian record show impact of prolong climatic forcing. Natl. Acad. Sci. USA. 105: 12145-12149.

Barry, J.C., M.E. Morgan, L.J. Flynn, D. Pilbeam, A.K. Behrensmeyer, S.R. Mahmood, I.A. Khan, C. Badgley, J. Hicks and J. Kelley (2002). Faunal and environmental change in the late Miocene Siwaliks of northern Pakistan. Paleobiol. 28: 172 .

Barry, J.C., S. Cote, L. Maclatchy, E.H. Lindsay, R. Kityo and A.R. Rajpar (2005). Oligocene and Early Miocene ruminants (Mammalia: Artiodactyla) from Pakistan and Uganda. Palaeont. Electr. 8(1): 1-29.

Batool, A., M.A. Khan, M. Akhtar and N.A. Qurashi (2014). New remains of Tragulids (Mammalia, Tragulidae) from the Dhok Pathan Formation of Hasnot (Late Miocene), Pakistan. Pakistan J. Zool. 46: 1323-1336.

Belmaker, M., S. Nelson, M.E. Morgan, J. Barry and C. Badgley (2007). Mesowear analysis of ungulates in the Middle to Late Miocene of the Siwaliks, Pakistan: Dietary and paleoenvironmental implications. J. Vertebr. Paleontol. 27: 46A46A.

Bernor, R.L., T. Coillet and D. Wolf (2014). Phylogenetic signatures in the juvenile skull and dentition of olduvai Eurygnathohippus cornelianus (Mammalia; Equidae). Riv. Itali. Di. Paleontol. c Strati. 120(2): 243-252.

Bibi, F. and E.S. Gulec (2008). Bovidae (Mammalia: Artiodactyla) from the Late Miocene of Sivas, Turkey. J. Verteb. Paleontol. 28: 501-519.

Butler, K., J. Louys and K. Travouillon (2014). Extending dental mesowear analyses to Australian marsupials with applications to six Plio-Pleistocene kangaroos from southeast Queensland. Palaeogeogr. Palaeoclimatol. Palaeoecol. 408: 11-25.

Cantalapiedra, J.L., R.G. FitzJohn, T.S. Kuhn, M.H. Fernandez, D. De Miguel, B. Azanza, J. Morales and A.O. Mooers (2014). Dietary innovations spurred the diversification of ruminants during the Cenozoic. Proc. R. Soc. B. 281: 2013-2746.

Fortelius, M. and N. Solounias (2000). Functional characterization of ungulate molars using the abrasion-attrition wear gradient: a new method for reconstructing paleodiets. Amer. Mus. Novit. 3301: 1-36.

Frazer, D. and J.M. Theodor (2013). Ungulate diets reveal patterns of grassland evolution in North America. Palaeogeogr. Palaeoclimatol. Palaeoecol. 369: 409-421.

Frazer, D., T. Zybutz, E. Lightner and J.M. Theodor (2014). Ruminant mandibular tooth mesowear: a new scheme for increasing paleoecological sample sizes. J. Zool. 294: 41-49. 
Hernesniemi, E., K. Blomstedt and M. Fortelius (2011). Multi-view stereo 3D reconstruction of lower molars of Recent and Pleistocene rhinoceroses for mesowear analysis. Palaeontol. Electr. 14(2): 2-15.

Kaiser, T.M. and N. Solounias (2003). Extending the tooth mesowear method to extinct and extant equids. Geodiversit. 25: 321-345.

Kaiser, T.M., D.W.H. Muller, M. Fortelius, E. Schulz, D. Codron and M. Clauss (2013). Hypsodonty and tooth facet development in relation to diet and habitat in herbivorous ungulates: implications for understanding tooth wear. Mam. Rev. 43: 34-46.

Khan, M.A. and M. Akhtar (2013). Tragulidae (Artiodactyla, Ruminantia) from the Middle Miocene Chinji Formation of Pakistan. Turk. J. Earth Sci. 22: 339-353.

Kubo, M.O. and E. Yamada (2014). The interrelationship between dietary and environmental properties and tooth wear: comparisons of mesowear, molar wear rate and hypsodonty index of extant sika deer populations. PLO. ONE. 9(3): e90745.

Mihlbachler, M.C., F. Rivals, N. Solounias and G. Semprebon (2011). Dietary change and evolution of horses in North America. Sci. 331: 1178-1181.

Nawaz, M.K., S.G. Abbas, M.A. Khan, M.A. Babar, M. Asim, R. Shahid and M. Akhtar (2019). Middle Miocene suids from Chinji Formation of Chabbar Syedan, Punjab, Pakistan. Pakistan J. Zool. 51(4): 1343-1353.

Patnaik, R., N.P. Singh, D. Paul and R. Sukumar (2019). Dietary and habitat shifts in relation to climate of Neogene-Quaternary proboscideans and associated mammals of the Indian subcontinent. Quat. Sci. Rev. 224. https://doi.org/10.1016/j.quascirev.2019.105968.

Pilgrim, G.E. (1937). Siwalik antelopes and oxen in the American museum of natural history. Bull. Amer. Mus. Nat. Hist. 72: 729-874.

Pilgrim, G.E. (1939). The fossil Bovidae of India. Palaeontol. Ind. 26(1): 1-356.

Rivals, F. and G.M. Semprebon (2006). A comparison of the dietary habits of a large sample of the Pleistocene pronghorn (Stockoceros onusrosagris) from the Papago Springs cave in Arizona to the modern Antilocapra americana. J. Verteb. Paleontol. 26: 495-500.

Rivals, F., M.C. Mihlbachler and N. Solounias (2007). Effect of ontogenetic age distribution in fossil samples on the interpretation of ungulate paleodiets using the mesowear method. J. Verteb. Paleontol. 27: 763-767.

Saarinen, J.J. and A. Lister (2016). Dental mesowear reflects local vegetation and niche separation in Pleistocene proboscideans from Britain. J. Quarter. Sci. 31(7): 799-808.

Samiullah, K., M. Akhtar, A. Ghaffar and M.A. Khan (2012). Giraffokeryx punjabiensis (Artiodactyla, Ruminantia, Giraffidae) from Lower Siwaliks (Chinji Formation) of Dhok Bun Ameer Khatoon, Pakistan. J. Sci. Technol. MSU. 31: 924.

Scott, R.S., J. Kappelman and J. Kelly (1999). The paleoenvironment of Sivapithecus parvada. J. Hum. Evol. 36: 245-276.

Semprebon, G., C.M. Janis and N. Solounias (2004). The diets of the Dromomerycidae (Mammalia; Artiodactyla) and their response to Miocene climatic and vegetational change. J. Verteb. Palaeontol. 24: 430-447.

Semprebon, G.M. and F. Rivals (2007). Was grass more prevalent in the pronghorn past? An assessment of the dietary adaptations of Miocene to recent Antilocapridae (Mammalia: Artiodactyla). Palaeogeogr. Palaeoclimatol. Palaeoecol. 253: 332-347.

Solounias, N., J.C. Barry, R.L. Bernor, E.H. Lindsay and S.M. Raza (1995). The oldest bovid from the Siwaliks, Pakistan. J. Vertebr. Palaeontol. 15: 806-814.

Solounias, N., F. Rivals and G.M. Semprebon (2010). Dietary interpretation and paleoecology of herbivores from Pikermi and Samos (Late Miocene of Greece). Paleobiol. 36(1): 113-136.

Solounias, N., G. Semprebon, M.C. Mihlbachler and F. Rivals (2012). Paleodietary comparisons of ungulates between the late Miocene of China, Pikermi and Samos in Greece. In: Neogene terrestrial mammalian biogeography and chronology of Asia. Wang X, Flynn LL, Fortelius M, editors. New York: Coloumbia University Press. 676-692.

Tariq, M. (2010). Paleoenvironmental study of Pakistan Siwaliks. Ph.D. thesis. GC Univ., Lahore, Pakistan. 107 pp.

Tariq, M. and N. Jahan (2014). Dietary evaluations and paleoecology of an extinct giraffid (Giraffokeryx punjabiensis) from Siwaliks of Pakistan. J. Anim. Plant Sci. 24(5): 1355-1365.

Ulbricht, A., L.C. Maul and E. Schulz (2015). Can mesowear analysis be applied to small mammals? A pilot-study on leporines and murines. Mammal. Biol. 80: 14-20. 